\title{
Sosialisasi Sampah Melalui Bank Sampah untuk Menyejahterakan Masyarakat di Desa TrukoJawa Tengah
}

\author{
${ }^{1}$ Hajizah Azmi Siregar ${ }^{2}$ Noya Yukari Siregar ${ }^{3}$ Yeni Selfia \\ ${ }^{1}$ Prodi Arsitektur, Universitas Selamat Sri, Jl. Soekarno-Hatta KM 03, Kendal, 51351 \\ ${ }^{2}$ Prodi Akuntansi, STIE IBMI, Jl. Perniagaan Baru NO. 33A, Medan, 20212 \\ ${ }^{3}$ Prodi Planologi, Universitas Selamat Sri, Jl. Soekarno-Hatta KM 03, Kendal, 51351
}

E-mail: amihajizahsiregar@gmail.com

\begin{abstract}
Abstrak - Indonesia menjadi negara terbesar kedua sebagai penyumbang sampah plastik setelah Cina. Dalam hal ini pemerintah Kabupaten Kendal memiliki berbagai cara untuk mengedukasi masyarakatnya agar sadar pentingnya pengelolaan sampah. Salah satu cara untuk menekan jumlah sampah adalah dengan mendirikan Bank Sampah. DesaTruko merupakan salah satu desa di kabupaten Kendal provinsi Jawa Tengah, desa ini terpilih dalam kegiatan pengabdian kepada masyarakat karena desa Trukobelum memiliki Bank Sampah dan masyarakat desa tersebut juga belum mengerti sistem menjalankan Bank Sampah. Hal tersebut terjadi dikarenakan masih kurangnya informasi tentang Bank Sampah dan pengolahan sampah tepat guna. Untuk mencapai tujuan tersebut, metode yang digunakan adalah:1) Mengedukasi masyarakat tentang program Bank Sampah 2) Sosialisasi pengelolaan Bank Sampah dan sampah 3) Sosialisasi dan pelatihan pengelolaan sampah telah menjadi proyek yang berharga.Dengan adanya artikel ini diharapkan dapat meningkatkan fasilitas di desa Truko maupun di desa lainnya dengan rencana pembentukan Bank Sampah. Mendirikan Bank Sampah merupakan cara untuk meningkatkan fasilitas desa karena dengan adanya Bank Sampah proses pengelolaan sampah akan lebih terarah, harapannyaartikel ini dapat memberikan informasi kepada masyarakat di Desa Truko maupun masyarakat di luar Desa Trukoproses pembentukan Bank Sampah dan pengelolaan sampah tepat guna menjadi barang bernilai jual.
\end{abstract}

Kata Kunci - Bank sampah, pemberdayaan masyarakat, daur ulang, desa truko

\begin{abstract}
Indonesia is the second largest contributor to plastic waste after China. In this case, the Kendal Regency government has various ways to educate the community to be aware of the importance of waste management. One way to reduce the amount of waste is by establishing Garbage Bank. Truko Village is one of the villages in Kendal district, Central Java province, this village was selected for community service activities because Truko village does not yet have a Garbage Bankand the village community also does not understand the system of running a Garbage Bank. This happens because there is still a lack of information about the Garbage Bank and proper waste management. To achieve this goal, the methods used are:1) Educating the public about the Garbage Bank program 2) Socializing the management of Garbage Bank and waste 3) Socialization and training on waste management has become a valuable project. The existence of this article is expected to improve facilities in Truko village and in other villages with a plan to form a Waste Bank.Establishing a Garbage Bank is a way to improve village facilities because with a Garbage Bank the waste management process will be more focused, it is hoped that this article can provide information to people in Truko Village and people outside Truko Village the process of forming a Garbage Bank and managing waste appropriately to become valuable goods selling
\end{abstract}

Keywords — Bank Sampah, community development, recycle, truko village

\section{PENDAHULUAN}

Sampah masih menjadi suatu permasalahan yang tidak dapat diselesaikan dengan benar sampai saat ini, khususnya di daerah-daerah yang tidak tersentuh oleh pemerintah pusat. Ada banyak upaya yang telah dilakukan pemerintah untuk menanggulangi sampah, satu upaya untuk mengatasi masalah persampahan tersebut adalah meningkatkan kemandirian dan kemampuan masyarakat dalam mengelola sampah sebagai cara untuk pemberdayaan masyarakat [1].
Proses pemberdayaan masyarakat pada pendidikan non formal merupakan wujud memperkuat presensi masyarakat, terutama pengetahuan tentang Sampah dan Bank Sampah karena kuota sampah yang semakin hari semakin meningkat dan masih banyak masyarakat yang belum memahami pengelolaan sampah yang baik dan benar. Proses pemberdayaan berfokus pada kegiatan yang semestinya dilakukan oleh masyarakat dan bermanfaat bagi masyarakat, dengan kata lain dapat dikatakan sebagai pendidikan masyarakat, Oleh sebab itu diperlukan kerjasama yang baik antara pemerintah, non pemerintah, organisasi, 
dan masyarakat untuk meyelesaikan permasalahan sampah yang ada.

Kuota sampah yang tidak terkendali menjadi dampak dari masyarakat di Indonesia yang masih tidak memahami cara mendaur ulang sampah, mendirikan Bank Sampah, dan kemana sampah ini akan di buang [2]. Permasalahan yang sering muncul dalam pengelolaan sampah adalah tingginya biaya operasional, sertasulitnya menemukan tempat pembuangan yang memadai. Akibat biaya operasional yang tinggi, menyebabkan sebagian besar daerah di Indonesia hanya dapat mengenakan biaya proses $60 \%$ dari semua limbah yang dihasilkan. Di sisi lain, sampah juga dapat menimbulkan penyakit jika tidak dikelola dengan baik dan tepat. Untuk mengurangi dampak negatif tersebut, maka masyarakat harus meningkatkan kualitas kebersihan lingkungan khususnya lingkungan hidup [3].

Padatnya jumlah penduduk serta terbatasnya lahan menyebabkan sampah sulit diselesaikan dengan tepat. Ketidaktahuan serta ketidakpedulian masyarakat juga menjadi alasan sampah terus terakumulasi di setiap sudut kota tanpa adanya pengelolaan yang tepat. Sampah rumah tangga merupakan contoh sampah yang tingkat pencemarannya sangat besar. Keberadaan sampah dapat menyebabkan pencemaran tanah dan air, menimbulkan bau yang tidak sedap, dan menjadi tempat berteduh sumber penyakit yang dapat mengganggu kesehatan dan keindahan lingkungan.Pengelola bank sampah juga harus kreatif, inovatif, dan berjiwa wirausaha agar bisa menjadi sumber pendapatan bagi masyarakat.

\section{ANALISIS SITUASI}

Desa merupakan salah satu unsur teritorial terkecil dalam satu wilayah Negara Republik Indonesia. Desa merupakan bagian yang tidak terpisahkan dari suatu Negara. Desa memiliki peran penting, meskipun sistem pemerintahannya diatur dan dikelola berdasarkan adat istiadat setempat.

Desa Truko merupakan sebuah desa yang terletak di Kecamatan Kangkung, Kabupaten Kendal. berdasarkan sejarahnya, desa truko merupakan daerah pemukimana. Tumenggung Bahurekso (Bupati Kendal) lalu memerintahkan seorang ulama yang bernama Kyai Truko untuk memimpin dan mengajarkan agama kepada masyarakat di wilayah pemukiman tersebut. Mulai saat itu wilayah yang dipimpin oleh Kyai Truko disebut dengan Padepokan Truko. Nama Kyai Truko diabadikan menjadi salah satu masjid di Desa Truko, yang dinamai Masjid At Tuqo. (www.truko.desa.id/public/menu/sejarahdesa)

Diawal kemerdekaan Republik Indonesia, Desa Truko masuk dalam wilayah Kecamatan Cepiring. pada tanggal 12 September 1992, Desa Truko masuk dalam wilayah Kecamatan Kangkung bersama 14 Desa lainnya hasil pemekaran wilayah Kecamatan Cepiring.

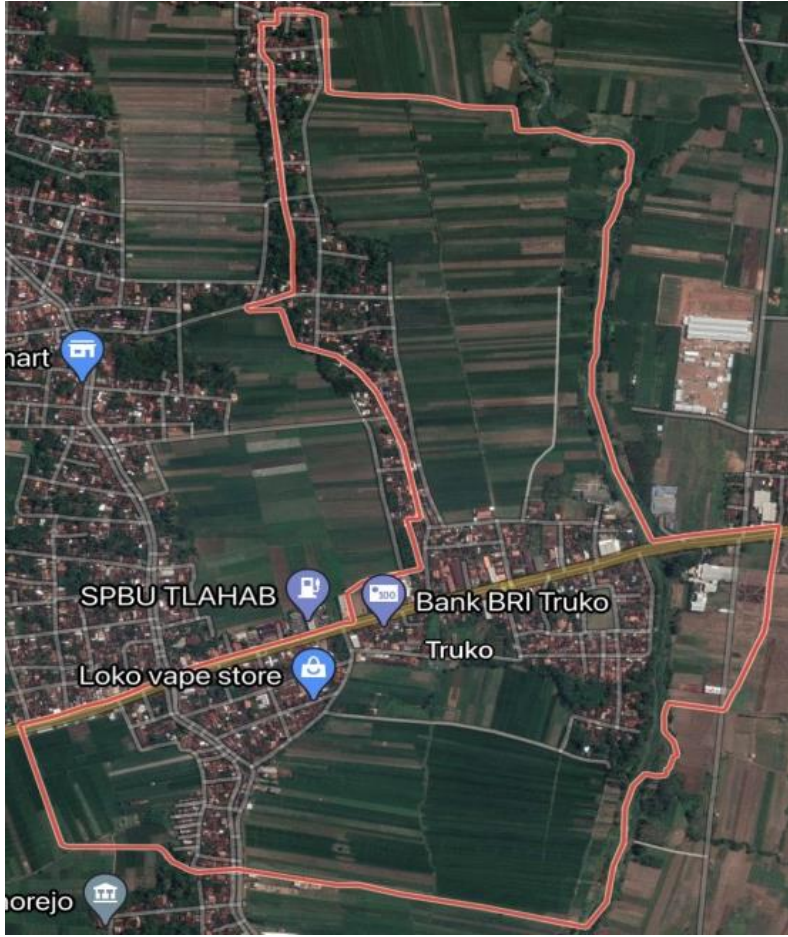

Gambar 1. Peta Lokasi Desa Truko

Berdasarkan observasi yang dilakukan, Desa Truko belum memiliki Bank Sampah maupun Tempat Pembuangan Sampah (TPS), sehingga membuat warga di desa tersebut membuang sampah ke sungai maupun ke Tempat Pemakaman Umum (TPU). Sampah yang berserakan memberikan dampak yang tidak baik dari segi estetika maupun kesehatan. Sampah menyebabkan daerah tersebut menjadi kotor dan akan menjadi sumber penyakit. Sebagian warga Desa Truko juga ada yang membakar sampah rumah tangga yang dapat menimbulkan polusi udara.

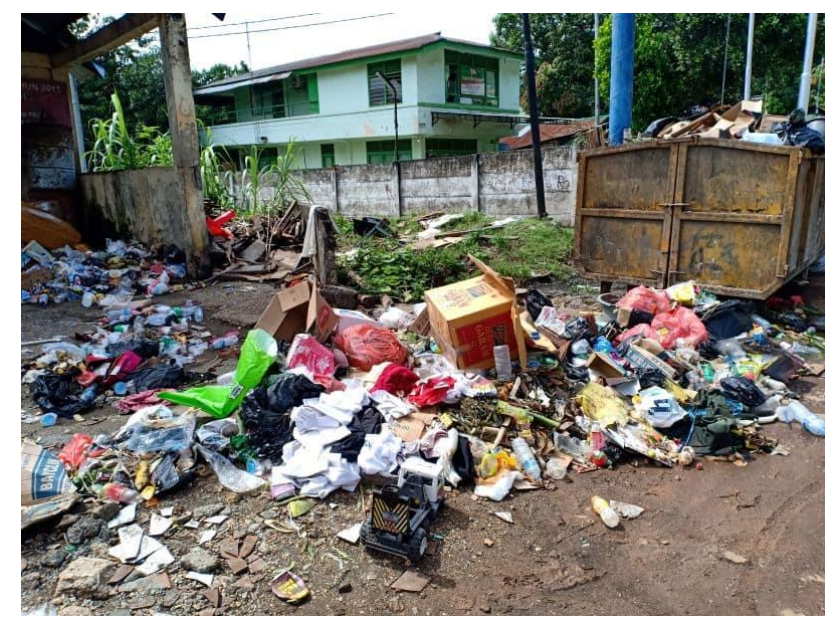

Gambar 2. Tempat Pembuangan Sampah di Desa Truko 


\section{Analisis Penduduk}

Jumlah penduduk Desa Truko adalah 4.914, dimana 2.806 adalah laki-laki dan 2.108 adalah perempuan [4]. Untuk lebih jelasnya akan di uraikan di bawah ini:

Tabel 1. Jumlah penduduk laki-laki berdasarkan usia.

\begin{tabular}{|c|c|c|c|}
\hline No & Uraian & $\begin{array}{c}\text { Jenis } \\
\text { Kelamin } \\
\end{array}$ & Jumlah \\
\hline 1 & Usia $\leq 3$ & Laki-laki & 72 \\
\hline 2 & Usia $>3$ sampai $\leq 6$ & Laki-laki & 93 \\
\hline 3 & Usia $>6$ sampai $\leq 12$ & Laki-laki & 181 \\
\hline 4 & Usia $>12$ sampai $\leq 15$ & Laki-laki & 94 \\
\hline 5 & Usia $>15$ sampai $\leq 18$ & Laki-laki & 79 \\
\hline 6 & Usia $>18$ sampai $\leq 24$ & Laki-laki & 159 \\
\hline 7 & Usia $>24$ sampai $\leq 29$ & Laki-laki & 132 \\
\hline 8 & Usia $>24$ sampai $\leq 34$ & Laki-laki & 109 \\
\hline 9 & Usia $>34$ sampai $\leq 39$ & Laki-laki & 156 \\
\hline 10 & Usia $>39$ sampai $\leq 44$ & Laki-laki & 154 \\
\hline 11 & Usia $>44$ sampai $\leq 49$ & Laki-laki & 121 \\
\hline 12 & Usia $>49$ sampai $\leq 54$ & Laki-laki & 118 \\
\hline 13 & Usia $>54$ sampai $\leq 59$ & Laki-laki & 101 \\
\hline 14 & Usia $>59$ sampai $\leq 64$ & Laki-laki & 95 \\
\hline 15 & Usia $>64$ sampai $\leq 65$ & Laki-laki & 12 \\
\hline 16 & Usia $>65$ sampai $\leq 74$ & Laki-laki & 72 \\
\hline 17 & Usia $\geq 75$ & Laki-laki & 39 \\
\hline
\end{tabular}

Tabel 2. Jumlah penduduk perempuan berdasarkan usia.

\begin{tabular}{lllr}
\hline No & \multicolumn{1}{c}{ Uraian } & Jenis Kelamin & Jumlah \\
\hline 1 & Usia $\leq 3$ & Perempuan & 86 \\
2 & Usia $>3$ sampai $\leq 6$ & Perempuan & 85 \\
3 & Usia $>6$ sampai $\leq 12$ & Perempuan & 198 \\
4 & Usia $>12$ sampai $\leq 15$ & Perempuan & 102 \\
5 & Usia $>15$ sampai $\leq 18$ & Perempuan & 65 \\
6 & Usia $>18$ sampai $\leq 24$ & Perempuan & 173 \\
7 & Usia $>24$ sampai $\leq 29$ & Perempuan & 113 \\
8 & Usia $>24$ sampai $\leq 34$ & Perempuan & 123 \\
9 & Usia $>34$ sampai $\leq 39$ & Perempuan & 170 \\
10 & Usia $>39$ sampai $\leq 44$ & Perempuan & 143 \\
11 & Usia $>44$ sampai $\leq 49$ & Perempuan & 113 \\
12 & Usia $>49$ sampai $\leq 54$ & Perempuan & 115 \\
13 & Usia $>54$ sampai $\leq 59$ & Perempuan & 103 \\
14 & Usia $>59$ sampai $\leq 64$ & Perempuan & 83 \\
15 & Usia $>64$ sampai $\leq 65$ & Perempuan & 8 \\
16 & Usia $>65$ sampai $\leq 74$ & Perempuan & 64 \\
17 & Usia $\geq 75$ & Perempuan & 41 \\
\hline
\end{tabular}


Jumlah alokasi dana pada tahun 2019 senilai Rp 839.900.000,-. Pengalokasian dana desa diharapkan mampu untuk mempercepat pembangunan desa tertinggal dan sangat tertinggal. Kebijakan pengalokasian dana desa juga mengacu kepada alokasi dana dasar, alokasi afirmasi, alokasi kinerja, serta alokasi formula (Badan Pemeriksa Keuangan, 2019).

\section{SOLUSI DAN LUARAN}

Berdasarkan rencana kegiatan yang telah dilakukan maka target luaran yang diharapkan setelah pelaksanaan kegiatan ini adalah:

1. Memberikan pemahaman serta kemandirian masyarakat dalam pengelolaan sampah melalui Bank Sampah, sehingga mampu menciptakan lingkungan yang bersih dan sehat.

2. Meningkatkan ekonomi keluarga di desa Truko melalui Bank Sampah.

\section{Rumusan Masalah}

Berdasarkan paragraph sebelumnya di jelaskan bahwa masalah yang ditemukan di desa Truko adalah tidak terdapat Bank Sampah, sehingga pengelolaan sampah di desa Truko belum dilakukan secara maksimal. Masyarakat di desa Truko masih belum mengetahui dengan baik bagaimana proses pembentukan Bank Sampah dan menjadikan sampah sebagai barang yang bernilai jual.

\section{Manfaat Kegiatan}

Kegiatan ini dilakukan untuk memberi manfaat bagi masyarakat. Adapun manfaat dari kegiatan ini adalah untukmemberdayakan masyarakat terutama di kalangan ibu-ibu. Dalam pelaksanaan kegiatan, ada target pencapaian meningkatkan pengetahuan masyarakat melalui Sosialisasi Pemberdayaan Masyarakat Dalam Pengelolaan Sampah Menjadi Barang Bernilai Jual melalui Bank Sampah. Dalam mencapai target pada indikator tersebut, maka sangat diperlukan komunikasi yang baik antara pemateri dengan peserta, sehingga informasi yang disampaikan dapat dimengerti. ,

Bank Sampah tersebut akan berfungsi sebagai sarana untuk menabung, dengan cara memilih sampah sesuai dengan jenisnya. Sampah yang disimpan di bank sampah merupakan sampah yang memiliki nilai ekonomis. Operasi Bank Sampah pada dasarnya sama dengan bank lain, termasuk nasabah, pembukuan dan manajemen. Pada bank biasanya nasabah tahu bahwa simpanan nasabah adalah uang, maka di Bank Sampah sendiri simpanan nasabah berupa sampah yang bernilai ekonomis.

\section{METODE PELAKSANAAN}

Metode ini dilakukan dengan tahap persiapan, sosialisasi, kemudian tahap mentoring. Dalam mencapai tujuan, peneliti melakukan diskusi tentang kondisi sampah di desa Truko, program dalam penanganan sampah, serta sosialisasi pendirian Bank Sampah.

Kegiatan ini diawali dengan melakukan sosialisasi tentang definisi sampah, jenis-jenis sampah dan proses pemilahan sampah yang merupakan dasar pengetahuan untuk pengenalan Bank Sampah. Kegiatan Tujuannya agar publik memahami pentingnya Bank Sampah dan pengelolaan sampah berbasis masyarakat.

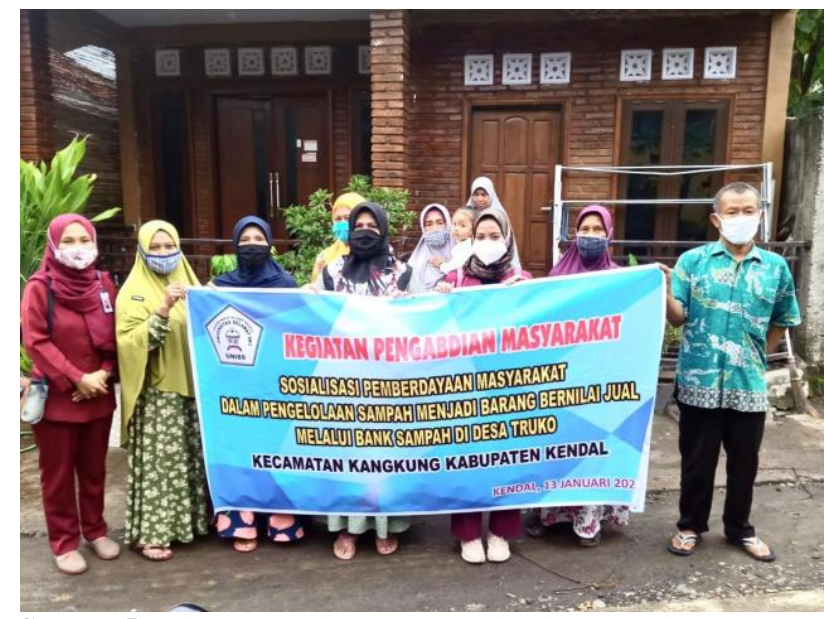

Gambar 5. Kebersamaan dengan Masyarakat di Desa Truko

Selanjutnya pada target kedua, yaitu sosialisasi pada pengelolaan bank sampah [6]. Berdasarkan hasil kegiatan pengabdian masyarakat yang dilakukan, bahwa jumlah sampah dan pengelolaan sampah dipengaruhi oleh kepedulian dan keikutsertaan seluruh anggota keluarga, terutama di Desa Truko. Jumlah anggota juga akan mempengaruhi partisipasi masyarakat dalam menabung Bank Sampah, hal ini karena jumlah anggota keluarga mempengaruhi jumlah sampah yang akan dihasilkan. Oleh sebab itu, jumlah anggota keluarga besar akan menghasilkan lebih banyak sampah dibandingkan keluarga kecil. Tingkat pengetahuan masyarakat akan jenis-jenis sampah dan bagaimana pengelolaannya terutama sampah kertas dan plastik merupakan hal yang mendasar dan penting dalam pengembangan dan pengelolaan Bank sampah terutama dalam prose daur ulang.

\section{HASIL DAN PEMBAHASAN \\ Hasil}

Bank sampah ada untuk menumbuhkan rasa kepedulian masyarakat, serta memupuk kesadaran masyarakat untuk dapat mengolah sampah secara bijak. Dalam melakukan sosialisasi Bank Sampah, masih ditemukannya ketidakpahaman masyarakat 
terkait pengolaan sampah melalui Bank Sampah. Hal ini tercermin dari jawaban yang diberikan oleh peserta kegiatan ketika dilakukannya sosialisai di Desa Truko.

Pada tahap dimulainya sosialisasi, peneliti memberikan stimulus serta penjabaran terkait sampah serta keuntungan dibentuknya Bank Sampah dikemudian hari. Setelah dilakukan penjabaran tersebut, masyarakat mulai memahami, hal ini dapat dilihat dari jawaban yang diberikan para peserta kegiatan. Sosialisasi Bank Sampah memberikan pemahaman baru kepada masyarakat di Desa Truko, bahwa Bank Sampah menjadi solusi yang baik dalam pengolaan sampah di Desa Truko.

\section{Pembahasan}

Sebelum dimulainya kegiatan sosialisasi kepada peserta kegiatan, mereka sama sekali tidak mengetahui tentang berapa banyak sampah yang dihasilkan oleh penduduk di Desa Truko dalam sehari, termasuk sampah rumah tangga.

Pembentukan bank sampah menjadi pengetahuan dasar bagi masyarakat untuk mengelola sampah sejak dari sumbernya, yaitu sampah rumah tangga. Pemberdayaan masyrakat ditujukan untuk mengembangkan pengetahuan serta keterampilan masyarakat, sehingga mampu memilah sampah organik dan non organik. Pengelolaan sampah dengan menabung ke bank sampah memberikan manfaat ekonomi, serta mewujudkan lingkungan yang sehat.

Langkah awal mendirikan unit bank sampah adalah menyediakan timbangan, karung penampung sampah, buku tabungan sederhana, buku catatan petugas, alat tulis dan kalkulator. Dalam pelaksanaannya, keuntungan akan diperoleh melalui penjualan sampah pada pengepul besar, hasil penjualan akan dikembalikan kepada warga masyarakat yang sudah menabung, sehingga hasilnya dapat dimanfaat untuk memenuhi kebutuhan hidup.

\section{KESIMPULAN DAN SARAN}

Kegiatan pengabdian kepada masyarakat tentang Sosialisasi Pemberdayaan Masyarakat dalam Pengelolaan Sampah Menjadi Barang Bernilai Jual Melalui Bank Sampah di Desa Truko Kecamatan Kangkung Kabupaten Kendal terlaksana dengan baik sehingga diharapkan ilmu yang telah di sampaikan dapat berguna bagi masyarakat di Desa Truko.

Peningkatan fasilitas di desa Truko dengan rencana pembentukan Bank Sampah dapat meningkatkan kesejahteraan dan pemberdayaan masyarakat setempat dan masyarakat luar desa untuk mengetahui proses pembentukan Bank Sampah hingga proses menjalankan sistem Bank Sampah.

Hasil sosialisasi menjadi komitmen seluruh peserta kegiatan dalam mewujudkan terbentuknya Bank Sampah. Pemerintah harus lebih mendukung lagi kegiatan-kegiatan yang meningkatkan fasilitas desa.

\section{DAFTAR PUSTAKA}

[1] Putra, Ismaniar. 2020. Pemberdayaan Masyarakat Melalui Pengelolaan Sampah Di Bank Sampah. Jambura Journal of Community Empowement 2 (1) (2020): 1-10.

[2] Nurhayati, Fitria, Kuswanto, Yniarno. 2019. "Bank Sampah Sebagai Upaya Pengelolaan Sampah Berbasis Masyarakat”. 392-400.

[3] Suprapto, Safitri, Susanti. 2018. Sosialisasi Bank Sampah Menjadi Motivasi Gerakan Masyarakat Desa Kebalankulon Kecamatan Sekaran. Abdimas Berdaya: Jurnal Pengabdian Masyarakat. 1 (2) (2018):82-88.

[4] Pemerintah Desa, n.y. www.truko.desa.id/ public/menu/kependudukandesa

[5] Barat. 2018. "Pemberdayaan Masyarakat Melalui Pengelolahan Sampah Menjadi Nilai Ekonomis dan Pembentukan Bank Sampah".1 (2017): 157-161.

[6] Selomo, Bintara, Birawida, Mallongi, Muammar. 2016. Bank Sampah Sebagai Salah Satu Solusi Penanganan Sampah di Kota Makassar. Jurnal MKMI. 12 (4) (2016): 232 240. 
